(0)

\title{
Zahra:
}

A Shattered Body and Voice from Lebanon

\section{Mireille Rebeiz}

\begin{abstract}
This article examines the gradual disintegration of Zahra, the young Lebanese protagonist of Hanan al-Shaykh's novel Hikayat Zahra (or The Story of Zahra). It studies the role of mothers in patriarchal societies and the impact of a conservative education on a daughter's emotional and psychological growth. Raised to believe in her inferiority due to her femaleness, Zahra constantly tries to live up to the social expectations for her gender. Each subsequent trial, however, ends in failure. When civil war breaks out in Lebanon, the resulting chaos temporarily relieves Zahra of the duties of her gender, but this break proves short-lived, as Zahra is killed. Drawing on a range of critical theory - particularly related to the female body, feminism, and disability - this article examines Zahra's private and public lives to trace the strong parallels between the social perception of her body and her complete annihilation.
\end{abstract}

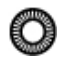

First published in Arabic in 1986 and translated into English in 1995, Hanan alShaykh's Hikayat Zahra (or The Story of Zahra) tells the story of a Lebanese girl who is emotionally and physically abused by her family and her patriarchal society. Zahra is a Muslim originally from a small town in the south, but, when the reader first meets her, she lives in Beirut before the outbreak of the Lebanese civil war in 1975. Zahra's life is full of contradictions: she lives in an urban environment, yet she maintains an attachment to rural values; she is expected to adhere to her conservative upbringing, yet she observes her mother having an affair with another man; she hates her mother for her deceit, yet she comes to her rescue when her father, who has discovered his wife's affair, beats them both severely. Zahra imitates her mother and discovers sex early in life. She undergoes two abortions after being sexually abused by her brother's friend and eventually suffers a nervous breakdown. Zahra obsessively scratches her pimples, finds comforting shelter in the bathroom, and walks around in complete silence. In an attempt to escape her immediate surroundings, Zahra leaves her family and joins her uncle in Africa, where she marries his friend Majed. The marriage is a 
complete failure. Divorced, Zahra returns to Beirut, where the war has broken out, but, ironically, Zahra finds freedom in the chaos of war. She falls in love with a sniper after he rapes her during their first encounter (indeed, she went to him thinking she could distract him and save lives); Zahra finds the rape pleasurable and experiences her first orgasm with him. A victim of traditional values, abused by men and terrorized by the war, Zahra's identity slowly fractures until it finally can no longer hold, for, in each of her escape attempts, she loses something of herself. Although the war provides her with the brief opportunity for selfreconstruction, this period of freedom is short-lived: she is ultimately killed by the sniper, her lover.

Zahra is a protagonist difficult to understand or identify with. At times, she seems unnecessarily unsociable; at others, she pushes the reader to question her sanity. Facing this human puzzle, this article seeks to study Zahra's gradual fragmentation and clearly identify what leads to the complete shattering of her sense of selfhood. Drawing on a range of critical theory, particularly related to the female body, feminism and disability, and on literary criticism, this article examines Zahra's private and public spheres to trace the strong correlation between the social perception of Zahra's body and her complete annihilation. Zahra's mother is the first person to crush her, as she treats her femininity as a form of irremediable disability. She sees Zahra as inferior to her brother, and, when Zahra is unable to properly perform her expected social duties, her mother marginalizes her and treats her as a grotesque person. Zahra's uncle contributes to the gradual shattering of her identity, as he sees her body as an extension of Lebanon, his lost nation, while Majed reduces Zahra to a body he can possess and with which he can have children. Finally, the sniper, fearing the reproductive powers of Zahra's body, sees her merely as an object to have sex with and then dispose. Zahra's body, therefore, takes on multiple meanings that vary depending on her social interactions, and this article aims to show that all these forcibly assigned meanings (the disabled and obedient female body, the body 
representative of a nation, the reproductive body, and the sexual body) are precisely what aggravate her silence and lead to her death.

\section{An Orange and Its Navel: Mother-Daughter Relationships}

Originally from the rural south of Lebanon, Zahra's mother is simultaneously the product and the guardian of traditional patriarchal values that perceive femaleness as a form of disability and assign it to the domestic sphere. Rosemarie Garland Thomson has extensively studied the relationship between the construction of femaleness and disability. In Extraordinary Bodies: Figuring Physical Disability in American Culture and Literature, as well as in her essay "Feminist Theory, the Body, and the Disabled Figure," she examines the many parallels that exist between femaleness and disability as social constructions. Female bodies and disabled bodies are presumed unable to function properly (or up to the expectations set by society) and are consequently considered inferior to male abled bodies. This conflation of femaleness with disability is not new; Tory Vandeventer Pearman detects it in Aristotle's and Plato's works as well as in medieval medical discourse (7-8). Freud, too, conflates femaleness with disability in his examination of women's sexuality, where he qualifies the female body as a "riddle"; Estela Welldon claims that he "asked his women colleagues to enlighten him about their own sexuality" (2). According to Thomson, this erroneous view of gender and disability is even more pronounced in patriarchal societies (Extraordinary Bodies 27).

Born and raised in this archaic view of femaleness, Zahra's mother mistreats Zahra and prefers her son over her daughter. Zahra points out this preferential treatment early in the novel:

I dared not reach for the chicken pieces since I had been given dinner earlier, my meal also consisting of melokhia, but without any chicken meat. Every evening it was the same. My mother would never give me a single morsel of meat. She always reserved for Ahmad, sometimes for my father. (al-Shaykh 11) 
Not only does the mother treat her son differently, but she also lies for him: "If Ahmad was late arriving home, my mother would rumple his bed and push a pillow down under the bedclothes. If my father asked, she would mumble, 'Ahmad is sleeping"" (25). According to Jane Flax, in her essay "The Conflict between Nurturance and Autonomy in Mother-Daughter Relationships and within Feminism,"

It is not only that the mother might value a son more, reflecting the higher social esteem enjoyed by men; but the mother, knowing the difficulties of being female in a man's world, might also wish that for the daughter's own sake, she could have been born male. Yet because the mother identifies so strongly with a girl child, she also wants the child to be just like her. (175)

In examining the mother's intentions, Jane Flax doesn't stop at the immediate reasons for discrimination against daughters but pushes the argument even further to look at the mother's background. One could safely assume that Zahra's mother was raised in a similar discriminatory environment. Identifying with her daughter and wishing for her to perform properly in society, therefore, she presumably treats her in the same way she was treated. Perhaps in an attempt to understand her mother's behavior, Zahra acknowledges that she may not know any differently: "Her ways never changed. Maybe she never ate chicken or meat herself" (al-Shaykh 11).

Regardless however of her intentions, the fact remains that the mother sees her daughter as inferior. She also sees her as odd and grotesque, constantly criticizing her physical appearance and deploring the fact that Zahra doesn't meet the social expectations of female beauty and gender roles. Both parents mock her acne problem instead of treating it as a medical issue: "That will be the day, when Zahra marries. What a day of joy for her and her pock-marked face!" (25); "What does your husband say when he looks at those pimples on your face?" (103).

In The Female Grotesque: Risk, Excess and Modernity, Mary Russo draws a link between the grotesque and the female body. The grotesque female body is a body 
in excess, a body that doesn't answer to social conventions. Unfamiliar and heterogeneous, the grotesque female body is perceived as challenging to norms and is consequently alienated from the general homogenous mass (11-13). Similarly, in Unbearable Weight, Susan Bordo demonstrates how norms for female beauty and fashion are social constructions established and maintained by men. Women frequently internalize these norms and cede to self-loathing when their bodies fail to fit these precise molds (8).

By considering acne as grotesque, Zahra's parents reduce her femaleness to her physical appearance and somehow conclude that she is unable to properly perform her social duties - that is, to find a husband and to keep him content. Susan Brownmiller writes about the relationship between skin and social constructions of identity, arguing that "[s]kin also functions as a means of social communication" (130) and that the social meanings of skin troubles vary between boys and girls. For boys, acne works as a rite of passage from puberty to manhood, whereas there is less tolerance to girls' skin troubles, as they are offered all kinds of products to conceal their acne. If anything, a girl's acne reflects her inability to conform to those higher standards of female beauty that privilege perfectly smooth and lighter skin (132). For Zahra, acne becomes a statement of her poor social performance. Sadly, she internalizes this discourse, which causes her to pick at her acne even more frequently until, ultimately, she finds relief at the sight of blood.

In examining mother-daughter relationships in the Arab world, Malek Chebel compares maternal love to servitude, as Arab mothers train their daughters to conform to social expectations and to fear the gaze of others (50-51). In her novel Women of Algiers in Their Apartment, Assia Djebar openly blames mothers for their daughters' psychological problems: "Hatred! [...] We suckle it with the milk of our exploited mothers! They've understood nothing: it's not only colonialism that's at the root of our psychological problems, but it's the belly of our frustrated women! When we're just fetuses, we're already damned!" (21). It is interesting to 
note the ambivalence of the mother figure in Arab women's literature. As Miriam Cooke points out in "Arab Women Arab Wars," the image of the Arab mother plays different roles in postcolonial literature:

In all of the Arab women's literature on postcolonial wars, images of motherhood have acquired centrality. The nurturing persona, who in the literature of the colonial period seemed bent on molding her daughter into her own oppressed shape, has multiplied so as to be able to play numerous roles. These mothers are both aggressive and pacific, patriotic and nationalist, desiring and destructive, martyr and prisoner. (25)

Zahra's mother certainly embodies these postcolonial characteristics of Arab motherhood, as she is simultaneously the victim and the safekeeper of the status quo of male dominance which jeopardizes her daughter's healthy psychological growth. As Flax writes, a mother plays an important role in her daughter's individuation process, for the daughter identifies with the mother, and it is, therefore, the mother's responsibility to foster a healthy separation towards individuation:

If the symbiotic experience has not been adequate, the process of separation and individuation that follows is also more difficult for the female infant. She lacks to some degree the firm base from which to differentiate. Furthermore, because she is expected to be like the mother, both as a person and in terms of her adult roles, there is less need for her to differentiate. $(175-76)$

Clearly, this statement applies to Zahra, who is unable to separate from her mother. Her abuse is revealed to the reader at the very start of the novel when Zahra and her mother are hiding behind the door, for Zahra's father has found out about his wife's affair and suspects that Zahra is complicit in covering it up: "We stood trembling behind the door. I was aware that my heartbeats mingled with the pulse in her hand as it stayed firmly pressed to my mouth. Her hand smelled of soap and onions. I wished she could keep it there for ever" (al-Shaykh 3). This 
violent opening scene symbolically predicts Zahra's voiceless life. Her mother silences her from the very beginning, and, despite her mistreatment, Zahra feels even more connected to her mother as their hearts beat together. Indeed, she wishes for her mother's hand to stay on her mouth forever.

Consequently, Zahra sees herself as an extension of her mother and repeatedly compares her relationship with her mother to "an orange and its navel" (al-Shaykh 8): "I wanted to draw her towards me, to draw myself close to her, to touch her face and have her eyes peering into mine. I wanted to disappear into the hem of her dress and become even closer to her than the navel is to the orange!" (8); "She actually needed my protection. She wanted us to be inseparable, like the 'orange and navel"" (12-13); "I wanted then to run to her, to pull her to me so we could again become like orange and navel" (14). It's worth mentioning that, though the violent incident that opens the novel occurs in Zahra's childhood, the narrative itself is recounted by an adult Zahra. She retroactively comes to understand the full meaning of her mother's actions, of the presence of a strange man in her mother's bedroom and of her father's violent reaction. However, despite this newly acquired information, she remains faithful to her mother and persists in comparing their relationship to the orange and its navel.

According to Evelyne Accad in Sexuality and War: Literary Masks of the Middle East, the orange here "is a symbol of her feeling as if she were at the center of the earth or back in the womb, a symbol of warmth and life" (45). In a way, Zahra longs for the embryonic stage during which she and her mother were united in one body. This unhealthy emotional bond prohibits Zahra from becoming an independent individual and constitutes the first step towards her eventual shattering. The next steps include her escape to Africa, her relationship with her uncle, her failed marriage, and her return to a war-torn Lebanon. 


\section{Zahra's Three Escape Attempts, or the Gradual Destruction of Her Body}

Zahra's mother mistreats her, and her father terrifies her. He is often depicted in his tramway uniform, and, for Zahra, this civic authority represents an abusive male authority, and her relationship with him seems to be strictly disciplinary:

I was afraid of my father's penetrating eyes - afraid he would discover what I had grown into, afraid he would kill me. My father was always brutal. His appearance seemed to express his character: a frowning face, a Hitler-like moustache above thick full lips, a heavy body. Do I misjudge him? He had a stubborn personality. He saw all life in terms of black or white. (al-Shaykh 24)

In response to her oppressive home environment, Zahra chooses to leave Lebanon. According to Joseph T. Zeidan in Arab Women Novelists: The Formative Years and Beyond, Zahra tries to escape her reality at three different times. The first time is when she departs to West Africa to stay with Hashem, her maternal uncle. This attempt is, however, unsuccessful. Banned from Lebanon, Hashem does not see Zahra as his niece but rather as a link to his lost family and nation. He invades Zahra's personal space, and their living situation becomes increasingly uncomfortable. Zahra escapes her uncle by marrying his friend Majed, which constitutes her second escape attempt. Sexually traumatized, Zahra is scared of Majed and even disgusted by him. Majed, on the other hand, perceives Zahra as a sexual object, as a body to possess rather than an equal partner, which increases Zahra's feelings of repulsion. Ultimately, Zahra divorces Majed and returns to Lebanon, where the war offers her a window to temporary freedom. This is her third escape attempt (Zeidan 206-8).

It is important to note that these escape attempts are, in fact, traps that will gradually lead to the loss of Zahra's voice - and her life. In the novel's second chapter, during what is intended to be a brief description of her uncle, Zahra's narrative is constantly interrupted by her uncle expressing his political views on Lebanon, the Middle East, and American foreign policy in the region. Zahra is silenced so completely that she loses her narrative privileges. Similarly, chapters 
three and four are told by Hashem and Majed, respectively, systematically silencing Zahra's voice as the novel progresses. As for her body, each escape attempt assigns to Zahra's body a new meaning with which she does not identify. She consecutively becomes the bodily representative of a lost nation, a vessel for the production of children, and a body with which to have sex. With each newly assigned meaning, Zahra loses control of her body until it becomes completely independent from her: it becomes pregnant despite her precautions, and it is finally killed by the sniper.

\section{Zahra as Nation}

The affection Zahra's uncle shows her is ambiguous in its intention: upon her arrival in Africa, at the airport, Hashem kisses her on the cheek and gives her a strong hug (al-Shaykh 19); at home, he enters her bedroom to wake her up and sometimes lies down next to her (20); at the movie theatre, he puts an arm around her shoulders and then holds her hands (21). Embarrassed, Zahra retreats into the bathroom, cries for hours, and then emerges completely silent. It is not clear to the reader if Zahra misunderstands her uncle's intentions and misinterprets his actions, especially considering that chapter three is narrated by Hashem, himself, and gives the reader a sufficiently different version of the same events so as to question Zahra's credibility.

In Hashem's view, Zahra symbolizes home. After their hug at the airport, he sighs in relief and says, "For the first time I have a feeling of being back home" (19). He admits hugging her tightly as she reminds him of his sister (69), and he explicitly identifies Zahra as "my one remaining link with my country" (68); without this link, he would be completely adrift and forgotten (68). Nostalgic for home, his sleep becomes agitated, so he impatiently waits for her to wake up in the morning (70). He holds her hands at the movie theatre, and, when she shows signs of extreme discomfort, he is shocked by her cold reaction: "I am you, you are your mother, your mother is daughter to my mother. Let me hold you in my arms. [...] You are the only witness to my destiny" (71). It is impossible to know 
whether or not Zahra has imagined her uncle's advances. Some critics, such as Abir Hamdar, have suggested that Zahra might be psychologically disturbed (20). Regardless of her mental health status, however, of primary importance is Hashem's perception of Zahra: for him, she is not merely his niece but an emissary of his lost nation.

Banned from Lebanon for political reasons, Hashem's only link to his home is Zahra, and she is his only living attachment to his past. Miriam Cooke, Evelyne Accad, and Sabah Ghandour have all discussed the fusion of women and nation in patriarchal nationalist discourses. In Women and the War Story, Miriam Cooke devotes a chapter, titled "Reimagining Lebanon," to defining the terms of nation and nationalism and demonstrating the link between nationalism and violence against women. In her terms, nation is a term difficult to confine to one strict definition, as it is "an emotional space in which individuals feel rooted and to which they feel they belong," while nationalism is the "action motivated by that feeling of connectedness" (268). And, in the particular case of Lebanon, there are a number of different nationalist discourses, all influenced by "competing ideologies which were generally organized into autonomous groups, tribal militias, each of whom claimed to represent the best interests" of Lebanon (269). For Evelyne Accad in "Guns and Roses," meanwhile, nationalism in Arabic countries defines itself in opposition to the west and takes pride in values it considers to be distinctly Middle Eastern, such as strict family structure, patriarchal social values, and conservative Islamic traditions (3). Objectified women thus become an essential part of the national political agenda, where they function "as signifier[s] of traditionalism, reservoir[s] of a communal identity" (Fayad 147). Trapped within his nationalistic and subjective historical views of Lebanon, Hashem fails to see Zahra as an individual. For him, she embodies the nation from which he has been expelled: "Lebanon, which he could not change, control, or take possession of when he was in Lebanon has arrived now in Africa in the figure of Zahra" (Ghandour 243). 
Zahra's individuality is pulverized as she becomes a territory to conquer at Hashem's hands, retreating ever deeper into silence and resignation despite her panic: "I could not bring myself to broach the subject, but wished I could simply say, 'Please don't ruin my visit. You are upsetting me.' [...] The sense of sadness completely enfolded me. I retreated into my shell" (23); "Oh, how I wish I could have said those words!" (34); "I shuddered, opened my mouth to try to speak, to cry, to threaten, to protest[.] [...] I ran to the bathroom piled with television sets and sat there crying in a voice that might have been heard all over Africa" (35). At different times, Zahra tries to speak up but fails. She seeks refuge in the bathroom and finds comfort in crying to the point of illness. She falls into almost catatonic silence, and the only time she exchanges words with her uncle is when she tells him that she has accepted Majed's marriage proposal.

\section{Zahra as Docile Body}

Zahra's second escape attempt, her marriage to Majed, quickly turns to disaster. As a victim of sexual abuse in her childhood, Zahra strongly hates Majed and cannot stand for him to touch her. Majed, conservative in his upbringing to the point of misogyny, perceives Zahra not only as a crucial rung in the expatriate Lebanese community's socio-economic ladder but also as a sexual object to which he, as her husband, is limitlessly entitled. Zahra, meanwhile, has a rather different relationship to sex. Her first encounter with sexuality is through exposure to her mother's affair, having seen her mother with her lover on several occasions. She describes a number of fragmented memories of the pair holding hands, sharing a bed, and lying under a tree. It is only retrospectively that Zahra comes to understand the real nature of their relationship:

I remember her sitting under a green walnut tree with his head in her lap as she sang to his closed eyes[.] [...]

Their secrets lost some of their mystery as I grew older and began regretfully to look back. Now I resented her all the more for having immersed 
me in a well of doubts and questions and magic while still so young and vulnerable. (9)

In Studies on Hysteria, Breuer and Freud extensively discuss infantile trauma, which, they claim, occurs when the subject is violently confronted by a shocking element that is immediately related to the subject's own identity. When the trauma occurs, the subject - inadequately equipped to understand, process, or respond to the shock - suffers in silence. Later in life, triggered by an insignificant reminder, the subject is projected into the past, and the traumatic incident finally makes sense. The time that elapses between the actual traumatic incident and its understanding as such renders the subject ill with traumatic neuroses:

The disproportion between the many years' duration of the hysterical symptom and the single occurrence which provoked it is what we are accustomed invariably to find in traumatic neuroses. Quite frequently it is some event in childhood that sets up a more or less severe symptom which persists during the years that follow. (Breuer and Freud 4)

As a result, the subject might suffer from low self-esteem, feel socially inadequate, or engage in self-destructive behaviours such as nervous tics, chronic vomiting, eating disorders, vision problems, and hallucinations.

Zahra was certainly marked by her mother's behaviour. Still a child, unable to provide proper consent or to identify right from wrong, she imitates her mother and engages in sex early on in her life. It is interesting to note that, in the Arab world, mothers are in charge of their daughters' sexual education. Considered to be the primary source of information, mothers often limit their daughters' sexual education to what is strictly necessary in order to be a good wife and mother. Sexuality, therefore, is tightly linked only to fertility and reproduction and excludes pleasure completely (Chebel 52-53). Zahra learns much more from her mother, however, by visually observing. Her first sexual encounter occurs with her 
brother's friend Malek. Married with child, he takes advantage of Zahra's youth, naivety, and silence, talking to her about love and friendship before asking her to join him in the garage:

He began kissing me; as I remained passive[.] [...] He wasn't at all vexed by my passivity while he was kissing me or as he made love to me. When, afterwards, I saw the blood, the proof of my virginity, on my tights and on the yellow coverlet, I said to him, 'Swear before God that we are married. It is all I ask.' But he wouldn't speak the words. (al-Shaykh 33)

Zahra continues to visit the garage and becomes pregnant twice. Her mother, her lover, and a female friend take Zahra to Damascus to get an abortion, and it is clear from the narrative that Zahra is very young when this incident occurs. She describes the event to the reader as a distant memory that she is unable to properly recall. She also acknowledges that, at the time, she could not understand why she was vomiting, why her mother and her friends were so annoyed with her, why she needed to see a doctor in Damascus, and why she was bleeding afterwards (6).

Later, Zahra is sexually molested by her cousin Kasem:

[A]s I was sleeping on the floor next to my grandfather, [...] it seemed as if a cold hand furtively moved in my panties. I woke and jumped up in a fright, and the hand suddenly disappeared. But the fear and the coldness had gripped me and shaken me. Even in that total darkness that could absorb no more darkness, I thought, for an instant, I saw the glint of Kasem's spectacles. (22)

Zahra's fuzzy memory and uncertainty in telling her stories are simultaneous indicators of her young age and her scotomization of trauma, which contribute to the narrative uncertainty she spreads throughout the novel, as though these incidents might have been imagined or dreamt rather than having really occurred. As a result of these traumatic experiences, Zahra has low self-esteem and becomes self-destructive: she scratches her pimples until they bleed; she rarely 
speaks; and she makes illogical, impulsive decisions, such as her consent to marry Majed.

Certainly, in Zahra's estimation, marrying Majed will allow her to run away from her uncle, but her plan fails again when she realizes she cannot stand her new husband: "The things that I feel whenever Majed comes close to me! Cold winds, cold, crowding me close with thousands of snails crawling closer, crawling across the mud as the winds blow ever more strongly, carrying the snails' foul odor which soaks into every pore" (93). Traditional and sexually frustrated, Majed sees Zahra as a Lebanese "ready-made bride" (73) in Africa who will save him the trouble and the cost of travelling to Lebanon to find a wife. As such, she is a thing to own, a body to have sex with whenever he pleases and to satisfy his feelings of deprivation (83). She is also his opportunity to become "a real human being" (75), which, in his opinion, translates into having a wife, a house, and children. Finally, Zahra represents for Majed a stepping stone to upper-class respectability since she comes from a well-known family (83).

Majed does not know Zahra, which he acknowledges at the start of chapter four. All of his observations of her are filtered through patriarchal stereotypes of femaleness. He considers her shyness and mood changes as normal for a woman (83). On their wedding night, he notices her disgust and does not address it; for him, "[g]irls are always irritable on their wedding night: fear and pain commingle. I felt she was in a state of disgust. That was also to be expected" (83). Majed's relationship with sex, meanwhile, is limited to prostitutes and masturbation, which, in both cases, revolves around satisfying only himself. Zahra's pleasure is never really part of the equation. On their wedding night, Majed expects Zahra to lose her virginity and to be in pain, and he is horrified to find that he is not her first sexual partner. Instantly, Zahra loses all of what she represents in his eyes, suddenly becoming a "[c]ursed woman! Daughter of a cursed woman!" (84). In Dehumanizing Women: Treating Persons as Sex Objects, Linda LeMoncheck argues that "treating persons as sex objects involves treating persons 
as less than the moral equals of other persons" (2). Majed sexually objectifies Zahra and sees her as just a body to have sex with, irrespective of her free will or desire, and his objectification of her is heightened when he realizes that she has been sexually active. From this point on, Majed deems Zahra morally unworthy and completely dehumanizes her.

It is, of course, crucial to mention that Zahra tries to match Majed's constructed image of her. She asks Majed to throw a party to celebrate their wedding, and she makes a concerted effort to act and dress like the other Lebanese women: "I tried to act the gay, happy woman[.] [...] I have tried to make myself into what is expected." (al-Shaykh 94); "That evening I tried very hard to be one of them. Majed put on records and invited everyone to dance. [...] I urged myself to stand up and dance, to banish my timidity there and then, so that I might become like the rest" (116). Despite all her efforts, however, she is unable to fit in, simultaneously hypervisible and ignored as a result of her difference: "At once, I felt their stares, and knew they were hardly stares of admiration. [...] I sat and tried to make conversation, but I felt how their eyes avoided mine." (94-95)

In Discipline and Punish, Michel Foucault discusses the relationship among social discipline, the body, and power, and he argues that the aim of our modern society is to optimize the body's utility in the service of the forces of governmentality. We do so by creating coercive disciplines in our various institutions, such as schools, the army, hospitals, prisons, and others. Consequently, we create what Foucault calls "docile bodies" (135), which require uninterrupted coercion and control (138). This control is often exercised through the gaze of others. In "Foucault, Femininity, and the Modernization of Patriarchal Power," Sandra Lee Bartky argues that Foucault's theorization of docile bodies overlooks gender and does not address discipline and coercion differently impact the female body: "[W]omen's movement," she writes, "is subjected to a still finer discipline. Feminine faces, as well as bodies, are trained to the expression of deference" (135). 
Zahra's social inadequacy is simultaneously the result of past trauma and a form of resistance to the coercive forces that aim to turn her into a docile body. These coercive forces manifest variously: from the mother who wants to pacify her and the father who scares her, to the uncle who sees her only as part of his nationalistic past and the husband who sexually objectifies her, to, finally, the stares of others who want her to conform to the standards of their patriarchal society. Zahra seems to be fighting over the ownership of her body - "I wanted to live for myself. I wanted my body to be mine alone. I wanted the place on which I stood and the air surrounding me to be mine and no one else's" (al-Shaykh 93) a struggle that motivates her return to Lebanon (after divorcing Majed), in an attempt to regain control over her increasingly shattered self.

\section{Zahra as Sex Object}

Zahra returns to a Lebanon beset with civil war, but she unexpectedly benefits from the pervasive chaos and acquires a new measure of freedom. In their article "The Double Helix," Margaret and Patrice Higonnet argue that war time interrupts traditional gender relations for the duration of conflict: a shift in the social structure necessarily occurs when women are compelled to assume roles typically reserved for men. By doing so, women redefine the parameters of their personal space, which was once restricted to the private, to henceforth include the public sphere. This newly acquired freedom and reconfiguration of female space, however, is provisory and will only last for the duration of the war. Once men return from the battlefield, women are relegated once more to the private sphere and are expected to resume their pre-war roles (31-32).

The war brings Zahra an unexpected inner peace, as she no longer has to perform her social obligations: "Here I am totally relaxed. I see no one. I speak as little as possible to my mother, and then only about food. The moment night falls I sleep soundly" (al-Shaykh 124). She expresses an unlikely serenity in the face of the worsening conflict: 
When I heard that the battles raged fiercely and every front was an inferno, I felt calm. It meant that my perimeters were fixed by these walls, that nothing which my mother hoped for me could find a place inside them. The idea of marrying again was buried deep by the thunder and lightning of the rockets. $(125-26)$

Despite this tranquility and disconnection from the world around her, however, the reality of the war eventually catches up with her, and she is in complete disbelief, asking herself, "Is all this truly happening outside our walls? [...] Is all this truly happening in Lebanon?" (129). She pays more attention to her new environment; she reads newspapers, amazed by the photos of the dead; she notices that Ahmad, her brother, has changed tremendously from the little boy she played with as a girl, now a militia man, addicted to drugs, bringing home the spoils of war.

Unable to fully comprehend what is unfolding around her and feeling powerless, Zahra makes another irrational decision. When she hears of a sniper perched on one of the empty buildings, she approaches him, naively believing that she will talk to him and thus distract him from his mission. During their first encounter, the sniper rapes her, and, unexpectedly, Zahra has her first orgasm: "Why had I felt no pleasure before, when I lay on everyday beds? Why had I never clawed at other men's backs as I did at that of this sniper? [...] Oh, sniper, let me cry out in pleasure so that my father hears me and comes to find me sprawled out so" (160-61). Scholars have responded differently to this complex moment in the novel. According to Accad, "Zahra's reaction to the war and to violence is masochistic. She submits herself to violent sex, thereby trying to forget the outside violence she cannot cope with" ("Guns and Roses" 5). For Zeidan, Zahra discovers sexual pleasure during the war "because the war has removed the authority figures from her life and suspended the usual rules for daily living, and this means Zahra's life and sexual behavior have become more her own than ever before" (215). For Cooke, meanwhile, the sniper frees Zahra from the settings of 
her daily life; he is what "allows the ugly Zahra to partake of excitement and therefore life" ("Beirut" 133). To put it differently, Zahra's sexuality blossoms in the most unexpected contexts of war and rape. Violence suspends the traditional patriarchal rules and allows Zahra to circulate freely in the city and to discover her body for the first time.

As Margaret and Patrice Higonnet have demonstrated, however, the newly acquired freedom of war time is only illusory. Zahra, despite attempting to take control of her sexuality with contraceptive pills, gets pregnant by the sniper. Trained to respond to male dominance, her body betrays her. Devastated, Zahra repeatedly compares the fetus insider her to a growing cancer. When she tells the sniper that she is pregnant, he does not seem upset and, instead, promises to marry her. On her way home from the sniper's rooftop, however, Zahra suddenly feels weak and is unable to walk straight. At first, she fears she is having a miscarriage; too late she realizes that she has been shot by her lover:

He's killed me. That's why he kept me there till darkness fell. Maybe he couldn't face pulling the trigger and dropping me to the ground in broad daylight. [...] The rain touches me again. I still lie where I fell. [...] I close my eyes that perhaps were never truly opened. I see rainbows processing towards me across the white skies with their promises only of menace. (al-Shaykh 215)

During her last moments, Zahra resigns herself to the reality that she was never really free, that she always was and always will be a subject of male dominance, and that the war was only a brief respite that offered the illusion of freedom. The sniper used Zahra's body for sex but to the exclusion of its natural capacity to become pregnant. As Kristeva examines at length in Power of Horrors: An Essay on Abjection, the pregnant body is feared for its reproductive powers, rendered abject for its destabilization of the boundaries between bodies, between the subject and the Other (77). For the sniper, Zahra was a body for sex alone. When it became the carrier of another body, an undesired other, it needed to be killed. 
It is reasonable to assert that Zahra is never seen in the novel as an independent human being with agency. For her immediate family and social environment, she is a female body, replete with all the meanings culturally associated with femaleness: she is the inferior, disabled female body that must learn obedience and accept its place in society; she is the bodily representative of nationalist memory and nostalgia; she is the vessel through which to deliver children; and, finally, she is sex object to be disposed of when no longer viable. As a result of all these assigned meanings, Zahra is mistreated by her family and sexually abused by several partners, slowly sinking into the cracks of an archaic patriarchal system that leaves little place for women to flourish. Her voice is silenced early in her childhood, and her body is finally eliminated by the same patriarchal forces. Gradually shattered, Zahra loses bits and pieces of herself to the point of complete disintegration. Zahra's shattering raises some serious questions that go beyond the parameters of a novel. To what extent does the burdening of women's bodies with preconceived meanings lead to the creation of conservative and patriarchal societies? In what ways do these meanings contribute into the rise of nationalism? Is it possible that the dismissal of women's voices and the shattering of their bodies can lead to war? Zahra's experience, though fictional, exemplifies the ways in which these questions are complexly intertwined. AlShaykh's novel thus reminds us that society cannot achieve peace when half of its population is shattered and misrepresented.

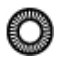

\section{Works Cited}

al-Shaykh, Hanan. The Story of Zahra. Translated by Peter Ford, Anchor, 1995. Accad, Evelyne. "Guns and Roses: On Sexuality and War." Little Magazine, vol. 2, no.1, 2001, pp. 1-7.

-. Sexuality and War: Literary Masks of the Middle East. NYU P, 1990. 
Bartky, Sandra Lee. "Foucault, Femininity, and the Modernization of Patriarchal Power." Writing on the Body: Female Embodiment and Feminist Theory, edited by Katie Conboy, Nadia Medina, and Sarah Stanbury, Columbia UP, 1997, pp. 129-54.

Bordo, Susan. Unbearable Weight: Feminism, Western Culture, and the Body. 1993. U of California P, 2004.

Breuer, Josef, and Sigmund Freud. Studies on Hysteria. Translated and edited by James Strachey, with Anna Freud, Basic, 2000.

Brownmiller, Susan. Femininity. Linden, 1984.

Chebel, Malek. "Mères, sexualité et violence." Être femme au Maghreb et en Méditerranée: Du mythe à la réalité, edited by Andrée Dore-Audibert and Souad Khodja, Karthala, 1998, pp. 49-59.

Cooke, Miriam. "Arab Women Arab Wars." Cultural Critique, vol. 29, 1994-1995, pp. 5-29.

-. "Beirut...Theatre of the Absurd...Theatre of Dreams...: The Lebanese Civil War in the Writings of Contemporary Arab Women." Journal of Arabic Literature, vol. 13, 1982, pp. 124-41. Print.

-. Women and the War Story. U of California P, 1997.

Djebar, Assia. Women of Algiers in Their Apartment. Translated by Marjolijn de Jager and Clarisse Zimra, U of Virginia P, 1992.

Fayad, Mona. "Reinscribing Identity: Nation and Community in Arab Women's Writing." College Literature, vol. 22, no.1, 1995, pp. 147-60.

Flax, Jane. "The Conflict between Nurturance and Autonomy in Mother-Daughter Relationships and within Feminism." Feminist Studies, vol. 4, no. 2, 1978, pp. 171-89.

Foucault, Michel. Discipline and Punish: The Birth of the Prison. 1975. Translated by Alan Sheridan, Vintage, 2012.

Ghandour, Sabah. "Hanan al-Shaykh's Hikayat Zahra: A Counter-Narrative and a Counter-History." Intersections: Gender, Nation, and Community in Arab Women's 
Novels, edited by Lisa Suhair Majaj, Paula W. Sunderman, and Therese Saliba, Syracuse UP, 2002, pp. 231-49.

Hamdar, Abir. The Female Suffering Body: Illness and Disability in Modern Arabic Literature. Syracuse UP, 2014.

Higonnet, Margaret R., and Patrice L.-R. Higonnet. "The Double Helix." Behind the Lines: Gender and the Two World Wars, edited by Margaret Randolph Higonnet, Jane Jenson, Sonya Michel, and Margaret Collins Weitz, Yale UP, 1987, 31-47. Kristeva, Julia. Powers of Horror. An Essay on Abjection. Translated by Leon S. Roudiez, Columbia UP, 1982. Print.

LeMoncheck, Linda. Dehumanizing Women: Treating Persons as Sex Objects. Rowan and Allanheld, 1985.

Pearman, Tory Vandeventer. Women and Disability in Medieval Literature. Palgrave Macmillan, 2010.

Russo, Mary. The Female Grotesque. Risk, Excess and Modernity. Routledge, 1994.

Thomson, Rosemarie Garland. Extraordinary Bodies: Figuring Physical Disability in American culture and Literature. Columbia UP, 1997.

-. "Feminist Theory, the Body, and the Disabled Figure." The Disability Studies Reader, edited by Lennard J. Davis, Routledge, 1997, pp. 279-92.

Welldon, Estela V. Mother, Madonna, Whore. The Idealization and Denigration of Motherhood. Karnac, 1992.

Zeidan, Joseph T. Arab Women Novelists: The Formative Years and Beyond. SUNY P, 1995.

Mireille Rebeiz is Assistant Professor of French and Francophone Studies in the Department of Cultural Studies and Comparative Literature at Stony Brook University. Her research interests include twentieth- and twenty-first-century francophone literature from the Maghreb and the Mashreq, contemporary Arabic literature, war literature by women, Beur literature, postcolonial cultures in France, and critical theory. 